\title{
The Contribution of Entrepreneurial Competency and Principal's Leadership on the Learning School and Its Implication on Teachers' Innovative Performance
}

\section{Dwi Ariyani ${ }^{1 *}$, Suyatno2}

1,2 Department of Education Management, Universitas Ahmad Dahlan, Yogyakarta, Indonesia *e-mail: acie2003@gmail.com

\begin{abstract}
The study aimed to examine the influence of entrepreneurial competency and the principal's leadership on the learning school and its implication on the teachers' innovative performance. The study belongs to quantitative research using a cross-sectional design with ninety teachers as the samples. The analysis concluded several findings. First, entrepreneurial competency reached the beta score of 0.107 , showing that it has no significant influence on learning school. Second, the managerial competency has a positive impact on the learning school, which was as much as 0.644 . Third, entrepreneurial competency reached the beta score of 0.022 , indicating that it has no significant influence on the teachers' innovative performance. Fourth, similarly, managerial competency reached a score of 0.005 , showing that it does not influence the teachers' innovative performance. Fifth, learning school negatively influences the teachers' innovative performance, with a score of -0.355 , showing its significant effect. Sixth, entrepreneurial competency through learning school positively influences the teachers' innovative performance, with a score of 0.059. And seventh, managerial competency through learning school positively affects the teachers' innovative performance, with a score of 0.233 . The research implies a relative influence of the principal's entrepreneurial and managerial competencies on developing the learning environment and the teachers' innovative performance at school.
\end{abstract}

Keywords: Entrepreneurial Competency, Managerial Competency, Learning School

\section{Introduction}

Recently, the development of entrepreneurship in education, particularly the principal's entrepreneurial leadership, has attracted academics or researchers (Neto et al., 2017; Ramadoni et al., 2016). Various factors caused it, one of which was the problems that require the schools to make some improvements through more creative and innovative ways. In Indonesia, the principals must have five competencies: personal, managerial, entrepreneurial, supervisory, and social competencies. The mapping of the principals' competencies in the national level held by the Institutions for Development and Empowerment of School Principal (LPPKS) and Educational Quality Assurance Institutions (LPMP) resulted in the score of the principals' competencies: $67.3 \%$ for personal competency, $47.1 \%$ managerial competency, 55.3\% entrepreneurial competency, $40.41 \%$ supervisory competency, and $64.2 \%$ social competency. The results indicated that the managerial and entrepreneurial competencies of the principals were low. Therefore, the government needs to handle matters because the principals' quality will affect school quality.

Entrepreneurial competency is the ability to change the opportunity into an action that moves the resources, such as personal, material, or non-material (Nwachukwu et al., 2017). Entrepreneurial leadership is the uniqueness of the leadership of another behavior. Enterpreneurial competency is a process of innovation and creativity through four dimensions: individual, organizational, environmental (in cooperation with the government), and education and institutions (Kuratko \& Hodgetts, 2004). It is creating a valuable object by sacrificing time and financial, psychological, and social risks to gain benefits and personal satisfaction. An entrepreneur tries to get an advantage through new creative and innovative

\footnotetext{
${ }^{*}$ Corresponding author.
}

Received November 12, 2020; Accepted August 18, 2021; Available online September 25, 2021

Copyright @ 2021 by Author. Published by Universitas Pendidikan Ganesha. 
ways and takes the opportunities viewed as problematic by many people. An entrepreneur assumes the chance by actualizing it in the organization through creativity and innovation to gain success and develop the organization (Suharsaputra, 2016).

As a leader, a principal is required to have entrepreneurial competency. According to the Regulation of the Minister of Education No 13 of 2007, the principal's entrepreneurial competency included the creation of useful innovation to develop the school; hard work to reach success; and strong motivation to perform the primary duties and functions as a leader; unyielding, entrepreneurial characters (Haris, 2018). A flexible organization characterizes entrepreneurship. The activities are closely related to innovation, proactiveness, and risk-taking (Arief et al., 2013). Entrepreneurs dedicate their time and efforts, assuming the fiscal, psychological, and social risks, as well as receiving gains and personal satisfaction (Hisrich, 1990). Unique characteristics, behaviors, and values of the principals indirectly affect the school entrepreneurship (Hughes \& Morgan, 2007). Entrepreneurship indicated that entrepreneurial education and needs for achievement influence entrepreneurial willingness (Baidi \& Suyatno, 2018).

A principal is required to have managerial abilities to take the initiative to improve the school's quality (Ismuha et al., 2016). The principal's managerial competency is the principal's ability to organize and encourage all school's elements (Haris, 2018). A principal taking the role of a manager, is responsible for planning, organizing, leading, and controlling the human resources, financial, physical, and information to achieve the goals effectively and efficiently (Nwachukwu et al., 2017). The Permendiknas Number 12 of 2007 and Number 28 of 2010 mentioned several managerial competencies of the principal. Those are (1) planning various program for the school; (2) developing the school organization as necessary; (3) leading the school in empowering the resources; (4) managing the changes and developing the school to create an effective learning organization; (5) creating conducive school culture and climate and innovation for the learners; 6) encouraging the teachers and staff for optimum empowerment; (7) managing the facilities and infrastructures; (8) maintaining the relation between the schools and society to find ideas, learning resources, and school funding; (9) fostering the learners, starting from receiving new students, placement, and development of their capacities; (10) developing the curriculum and learning activities following the direction and goals of the school; (11) managing the financial based on accountability, transparency, and efficiency; (12) managing the school administration to support the goal achievement; (13) maintaining good relation between society as parents and users; (14) organizing the special unit of the school to keep the learning activities and learners at school; (15) managing the school information system to support the programs for decision-making; (16) utilizing the advanced information and technology to improve the school learning and management; (17) monitoring, evaluating, and reporting the implementation of the school program using appropriate procedures and the follow-up.

The research by Cantillon et al. in found that entrepreneurial leadership provides the space to optimize the potentials and motivate subordinates to work creatively and innovatively. The principal, serving as the school manager and leader, takes the role to encourage, inspire, and support the teachers to work creatively (Mahmud \& Palopo, 2019). Principal with an entrepreneurship spirit can encourage the teachers to create innovation (Sahnan, 2016). School culture influences teachers' innovative performance. Besides, entrepreneurial leadership gives the members freedom of creativity and innovation (Chen, 2007; Cogliser \& Brigham, 2004; Collins et al., 2004; Eyal \& Kark, 2004).

Teachers' innovative performance is one crucial indicator in facing various challenges in all aspects of life. Schools regularly received improvement programs, but the implementation was below the expectation, of which one of the causes was the teachers' performance. School improvement needs innovation to increase educational quality. Unfortunately, not all educational institutions are ready to face the changes. Indeed, it requires the schools to keep innovating. The principal, the key influencing factor, has the authority to move, provide, and support the learning school. His managerial competence influences entrepreneurial competence, leading to the success of organizational performance. It is necessary to investigate the matter, to know the effect of entrepreneurial 
competence on the teachers' innovative performance. It is expected that principals can improve their entrepreneurial and leadership competence through education and training programs. This way, they can develop their competence, allowing them to develop the teachers' innovative performance. The more innovative is the teacher and the students, the better the education quality.

Studies about the principal's entrepreneurial and managerial competencies have been conducted. First, stated that a manager is an internal factor affecting the organization (Baltaci, 2017). The manager's roles contribute to the excellence of the internal resources of the organization. Second research found that organizational behavior results from individual outcomes in the form of performance; thereby, the organizational culture influences the individuals' performance (Wibowo, 2013). The other research explained a positive correlation between entrepreneurial leadership, teachers' empowerment, and school effectiveness. Teachers' empowerment turns out to be the mediator of both mentioned variables (Sani Dahiru et al., 2017). Entrepreneurial leadership refers to empowering the leaders in overcoming relevant problems based on their responsibilities and roles (Dimovski et al., 2013).

There has been much research on the relation between entrepreneurial orientation and organizational performance (Arief et al., 2013; Jia \& Phillips, 2014). The problems that occur at school need external supports, although the school has limited the regulations for entrepreneurial activities (Baltaci, 2017). The previous study showed that entrepreneurial competency influences organizational performance (Nwachukwu et al., 2017). In the same way, entrepreneurial competency improves organizational performance and competitiveness (Sajilan et al., 2015). Unlike the previous studies, the present study aimed to measure the contribution of entrepreneurial and managerial competencies of the principals to the learning school and the implication on the teachers' innovative performance. Therefore, the research was necessary, particularly to help the policymakers improve the principals' competencies, in that a school needs the learning to enhance the capability to overcome the rapid environmental changes.

\section{Method}

The research was a quantitative study using the ex post facto approach. It was conducted to test the hypotheses mentioned above. The samples included ninety teachers that consisted of 41 teachers from SMA Negeri 2 Magelang and 49 from SMA Negeri 4 Magelang. They were selected using a quota sampling method. The research used four variables. The independent variables were the principal's entrepreneurial competency (X1) and the principal's managerial competency $(X 2)$; the intervening variable was the learning school (Y), and the dependent variable was teachers' innovative performance (Z). The research design was presented in Figure 1.

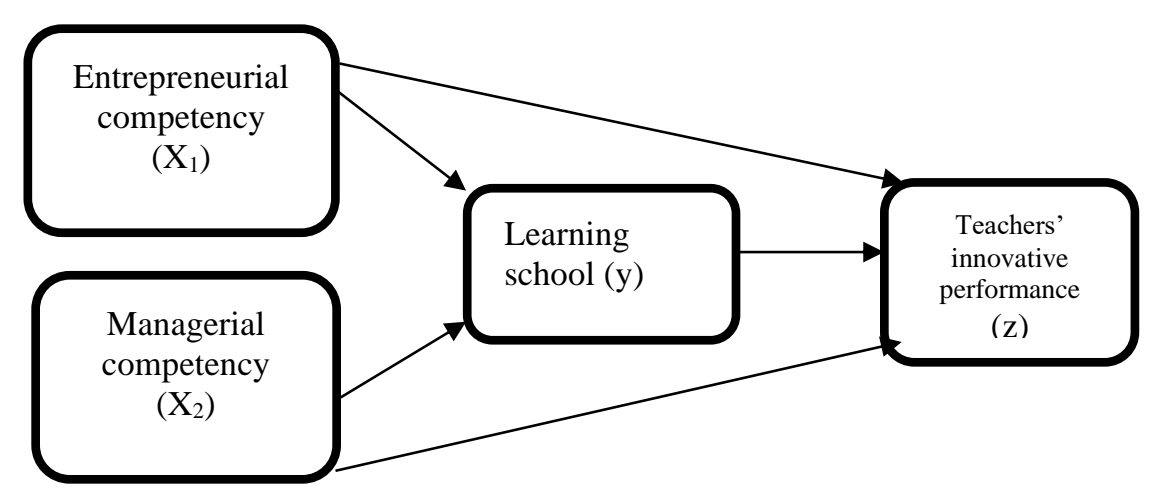

Figure 1. The relation between Variable $X_{1}, X_{2}, Y$, and $Z$ 
The instrument used was a questionnaire employing the Likert scale. It comprised four categories: entrepreneurial competency, managerial competency, learning school, and teachers' innovative performance. Before the instrument was distributed, it was validated using the Pearson Product Moment formula, and the reliability was tested using Alpha's formula. After the validation, twenty-four items of the first questionnaire were considered valid and one invalid; eighteen items of the second questionnaire, twenty-five of the third, and twenty-four of the fourth were valid. The data were analyzed using the path analysis technique. Hypothesis testing took several steps. The first was the path prerequisite test model I, which included multi-co-linearity, auto-correlation, linearity, and path coefficient. The second was path prerequisite test model II consisting of normality, autocorrelation, linearity, and path coefficient model 2 .

\section{Result and Discussion}

\section{Results}

\section{Prerequisite Test}

To ensure the accuracy, consistency, and non-biased parameters, it is necessary to conduct path prerequisite model 1 and II. The path normality test Model 1 resulted in the significance score of each variable: entrepreneurial competency $0.069>0.05$; managerial competency $0.242>0.05$; learning school $0.072>0.05$; and teachers' innovative performance $0.136>0.05$. The normality test Model II produced exactly similar results as Model I. If the sig value is above 0.05 , the data are normally distributed, while if it is below 0.05 , the data are not normally distributed. Therefore, it can be concluded that the variables of the present study were normally distributed.

The calculation of path prerequisite test Model I proved that the correlation among independent variables was low (the correlation between entrepreneurial and managerial competencies was 0.326 ). Hence, there was no multi-co-linearity between the independent variables used in the regression model. Similar results were produced in the path prerequisite test Model II. The correlation between entrepreneurial competency and managerial competency was 0.326 . Further, entrepreneurial competency and learning school were 0.317; managerial competence and learning school was 0.679; entrepreneurial competency and teachers' innovative performance was -0.088; managerial competence and teachers' innovative performance was -0.299 , and learning school and teachers' innovative performance -0.345 . Therefore, multicollinearity did not occur among the independent variables of the present study. Autocorrelation did not occur if $-2 \leq \mathrm{DW} \leq 2$. The calculation using the path prerequisite model I resulted in the Durbin Watson score as much as 1.895 . It means that autocorrelation did not occur in the multiple regression models. In Model II, the Durbin Watson score was 1.623. Similarly, there was no autocorrelation in the multiple regression models.

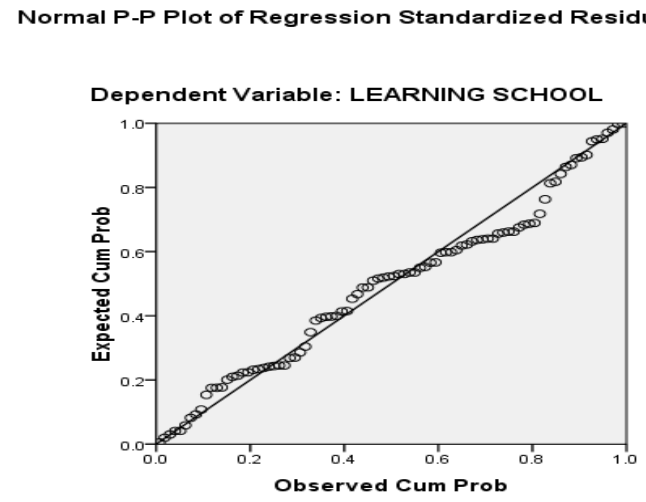

Figure 2. Linearity Test 
Figure 2 concluded that if the line was formed from the bottom left corner to the upper right corner, the linearity is fulfilled. It means that the regression model has fulfilled all the requirements. In other words, the regression model of the path analysis was appropriate.

\section{Path Coefficient}

The Model 1 coefficients can be found through the significance value. The significance value of variable $X 1$ was 0.198 , and $X 20.000$. Therefore, it can be concluded that in regression model I, variable XI did not significantly influence $Y$, while $X 2$ influenced it because the score was below 0.05 . The R-square value of the Model Summary model was 0.471 . It shows the contribution of $\mathrm{X} 1$ and $\mathrm{X} 2$ to $\mathrm{Y}$, which was $47.1 \%$. The $\mathrm{e} 1$ can be calculated using the formula $\sqrt{ }(1-0,461)=0,734$. The Model 2 coefficients can be found through the significance value of the three variables, which were $0.012,0.836$, and 0.973 for variable $Y, X 1$, and $X 2$, respectively. The significance value of $Y$ was below 0.05 , meaning that the regression model 2 significantly influenced $Z$. Meanwhile, both $X 1$ and $X 2$ were above 0.05 . Therefore, the variables did not substantially affect variable $Z$. The $R$-square value of the Model Summary table was 0.119 . It shows the contribution of $X 1, X 2$, and $Y$ to $Z$ was $11.9 \%$. The e2 was calculated using the formula e2 $=\sqrt{ }(1-0,119)=0,938$.

\section{Hypothesis Testing}

First, the analysis of $X_{1}$ influence on $Y$ can be tested by calculating the t-value, considering that there is a linear relation between $\mathrm{X}_{1}$ and $\mathrm{Y}$. If $t_{\text {count }}>t_{\text {table }}, \mathrm{HO}$ is rejected, and $\mathrm{H} 1$ accepted. Conversely, if $\mathrm{t}_{\text {count }}<\mathrm{t}_{\text {table, }} \mathrm{HO}$ is accepted, and $\mathrm{H} 1$ is rejected. In the present study, the $t_{\text {table }}$ was 1.987 . The SPSS calculation showed that the $t_{\text {count }}$ was $1.297<t_{\text {table }}$, which was 1.991. Therefore, $\mathrm{H} 0$ was accepted, and $\mathrm{H} 1$ was rejected. It means that there is no linear correlation between $X_{1}$ and $Y$. Thus, variable $X_{1}$ did not influence $Y$. The Beta coefficient value (in Standardized Coefficients Beta column) was 0.107 or $10.7 \%$, indicating that it is not significant $(0.198>0.05)$. Second, the analysis of $X_{2}$ influence on $Y$ can be tested by calculating the t-value, considering that there is a linear relation between $X_{1}$ and $Y$. If $t_{\text {count }}$ $>t_{\text {table, }}, \mathrm{HO}$ is rejected, and $\mathrm{H} 1$ accepted. Conversely, if $\mathrm{t}_{\text {count }}<\mathrm{t}_{\text {table, }}, \mathrm{HO}$ is accepted, and $\mathrm{H} 1$ is rejected. In the present study, the $t_{\text {table }}$ was 1.987 . The calculation using SPSS showed the

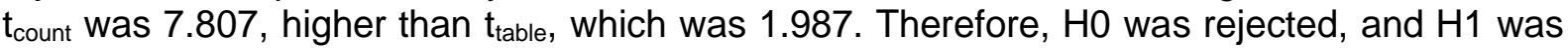
accepted. It proved a linear correlation between $X_{2}$ and $Y$, meaning that $X_{2}$ influenced $Y$. The Beta coefficient score was 0.644 or $64.4 \%$, meaning that the influence was significant $(0.000$ $<0.05)$.

Third, the analysis of $X_{1}$ influence on $Z$ can be tested by calculating the t-value, considering that there is a linear relation between $X_{1}$ and $Y$. If $t_{\text {count }}>t_{\text {table }}, H 0$ is rejected, and $\mathrm{H} 1$ accepted. Conversely, if $t_{\text {count }}<t_{\text {table, }} \mathrm{HO}$ is accepted, and $\mathrm{H} 1$ is rejected. In the present study, the $t_{\text {table }}$ was 1.987 . The SPSS calculation showed that the $t_{\text {count }}$ was 0.208 , below the $t_{\text {table, }}$ which was 1.992. Therefore, $\mathrm{H} 0$ was accepted, and $\mathrm{H} 1$ was rejected. It means that there is no linear correlation between $X_{1}$ and $Z$. Thus, variable $X_{1}$ did not influence $Z$. The Beta coefficient value (in Standardized Coefficients Beta column) was 0.022 or $2.2 \%$, indicating that it is not significant $(0.836>0.05)$. Fourth, the analysis of $X_{2}$ influence on $Z$ can be tested by calculating the t-value, considering that there is a linear relation between $X_{1}$ and $\mathrm{Y}$. If $\mathrm{t}_{\text {count }}>\mathrm{t}_{\text {table }}, \mathrm{HO}$ is rejected, and $\mathrm{H} 1$ accepted. Conversely, if $\mathrm{t}_{\text {count }}<\mathrm{t}_{\text {table }}, \mathrm{HO}$ is accepted, and $\mathrm{H} 1$ is rejected. In the present study, the $t_{\text {table }}$ was 1.987. The SPSS calculation showed that the $t_{\text {count }}$ was 0.034 , higher than the $t_{\text {table, }}$, which was 1.992 . Therefore, $H 0$ was accepted, and $\mathrm{H} 1$ was rejected. It means that there is no linear correlation between $\mathrm{X} 2$ and $\mathrm{Z}$. Thus, variable $X_{2}$ did not influence $Z$. The Beta coefficient value (in Standardized Coefficients Beta column) was 0.005 or $0.5 \%$, indicating that it is not significant $(0.973>0.05)$.

Fifth, the analysis of $Y$ influence on $Z$ can be tested by calculating the t-value, considering a linear relation between $\mathrm{Z}$ and $\mathrm{Y}$. If $t_{\text {count }}>\mathrm{t}_{\text {table, }} \mathrm{H} \mathrm{O}$ is rejected, and $\mathrm{H} 1$ accepted. Conversely, if $t_{\text {count }}<t_{\text {table }}, \mathrm{H} 0$ is accepted, and $\mathrm{H} 1$ is rejected. In the present study, the $t_{\text {table }}$ was 1.987. The SPSS calculation showed that the $t_{\text {count }}$ was -2552 , higher than the $t_{\text {table, }}$ which was 1.992. Therefore, $\mathrm{H} 0$ was rejected, and $\mathrm{H} 1$ was accepted. It proved a linear correlation between $\mathrm{Y}$ and $\mathrm{Z}$. Therefore; variable $\mathrm{Y}$ influenced $\mathrm{Z}$. The Beta coefficient value 
(in Standardized Coefficients Beta column) was -0.355 or $-35.5 \%$, indicating that it is significant $(0.012<0.05)$. Below is the table for the t-test.

Sixth, the analysis of $X_{1}$ influence on $Z$ through $Y . X_{1}$ directly influenced $Z$, with a score of 0.022 . Meanwhile, the indirect influence of $X_{1}$ through $Y$ on $Z$ was by multiplying the $X_{1}$ beta score on $Y$ with the $Y$ beta score on $Z(0.107 \times 0.355)$. The result was 0.037 . This way, the total influence is obtained by adding the direct and indirect influence $(0.022+$ 0.037 ), which resulted in 0.059 . Therefore, the total influence score was 0.022 , while the indirect was 0.059 . It means that the indirect influence was more significant than the direct one. In other words, $X 1$ indirectly influenced $Z$. Seventh, the analysis of $X_{2}$ influence on $Z$ through $Y . X_{2}$ directly influenced $Z$, with a score of 0.005 . Meanwhile, the indirect influence of $X_{2}$ through $Y$ on $Z$ can be calculated by multiplying the $X 2$ beta score on $Y$ with the $Y$ beta score on $Z(0.644 \times 0.355)$. The result was 0.228 . This way, the total influence is obtained by adding the direct and indirect influence $(0.005+0.228)$, which resulted in 0.233 . Therefore, the total influence score was 0.005 , while the indirect was 0.233 . It means that the indirect influence was more significant than the direct one. In other words, X1 indirectly influenced $Z$.

\section{Discussion}

The research aimed to test the seven hypotheses proposed. The analysis results showed that three hypotheses were rejected, and four others were accepted. First, entrepreneurial competency negatively influences learning school, with a Beta coefficient value of 0.107 or $10.7 \%$. It was different from the previous study, stating that it influenced the learning environment (Nwachukwu et al., 2017; Suharsaputra, 2016). Entrepreneurial competency is the ability to change ideas into action (Nwachukwu et al., 2017). Entrepreneurship is an innovation process that includes vision, changes of ideas, and ability related to chances. A research found that poor leadership causes employees to move from the organization, have the low working motivation, develop an unhealthy working circle, and develop higher stress (Senny et al., 2012). Creativity and innovation can exist in individuals or groups, but they need support (Suharsaputra, 2016). Changes need the synergy of all school members. A change identified by a person has additional damage. Learning school is an organization that requires all members to achieve school goals. Changes need to be built in the process (Macbeath \& Mortimore, 2005). However, an organization that involves too many nonmembers tends to find difficulties in making changes. Entrepreneurial leadership is the transformer of all competencies owned by a school principal (Suharsaputra, 2016). The hypothesis test concluded that a principal having only entrepreneurial competency does not affect the learning school because it needs synchronous energy to optimize the roles and duties of each organization member.

Second, managerial competency positively influences the learning school with the Beta coefficient score of 0.644 or $64 \%$. The finding supports previous studies, mentioning that good managerial competency helps create a comfortable and conducive learning environment. Principal, as a manager, is involved in planning, organizing, leading, and controlling the human resources, finance, and information, achieving the school goals (Nwachukwu et al., 2017). To create some changes, a principal does not necessarily maintain the status quo because there are teachers, staff, and students. The principal serves to provide comprehensive roles and functions to the school members. He should be able to ensure the optimum implementation of the school potentials (Kunandar, 2007). The development program for the teachers' performance could be conducted by dividing the duties in accordance with each ability through lesson study among teachers (Ismuha et al., 2016). The school needs to learn to overcome rapid environmental changes. Learning school is a school organization with the prominent role of organizing the learning. The organization's attitude to changes determines the school's success in anticipating the unexpected occurrence. A school improvement program is necessary to facilitate changes and innovation (Suharsaputra, 2016). Managerial competency significantly influenced the working climate and teachers' performance (Walid et al., 2013). Changes need to be structured and habitualized so that the organization members perform the learning process as part of their roles and functions. The research about an effective school has proven the importance of 
school culture, with leadership as the cultural elements (Earley \& Weindling, 2004). Similarly the principal's managerial competency would contribute to the management's implementation (Haris, 2018). The present study proved that the competency could shape the learning school to increase educational quality.

Third, entrepreneurial competency did not positively influence the teachers' innovative performance, with the Beta coefficient score of 0.022 or $2.2 \%$. The hypothesis failed to prove the previous studies' findings, where a headmaster with good entrepreneurial competency can motivate teachers to be more innovative. Indeed, creativity and innovation are the foundation to implement entrepreneurial competency (Syam et al., 2018). The principal's leadership model is not a coincidence. Instead, there is a soft dimension influencing individuals' performance. The teachers' creativity and innovation are not limited to the classroom activities but also through leadership roles that support the democratic values of the school organization (Suharsaputra, 2016). Entrepreneurship is the individual's characteristics that can be transformed within an organization. It contributes to the innovation created by the organization. However, the present study showed that the principal's entrepreneurial competency did not positively influence the teachers' innovative performance. It can affect the performance of the school provides the transformational facilities.

Fourth, managerial competency did not positively influence the teachers' innovative performance, with the Beta coefficient score as much as 0.005 or $0.5 \%$. The competency is the principal's ability to empower the teachers through cooperation and involvement of all parties in various activities supporting the school program (Mulyasa, 2006). Internal and external factors influence innovative teachers' performance. The latter is related to the environment where a teacher works. It can be at school or in society (Suharsaputra, 2016). Therefore, teachers' innovative performance will be a success if the environment supports the teachers to develop. The present study found that the managerial competency did not significantly influence the teachers' performance because the principal focused on achieving the school goal instead of on the teachers' improvement. If the principal only encourages the teachers to improve in the learning activities, the managerial competency does not affect the teachers' performance. Instead, the teachers' performance is influenced by the professional development process. Training or lectures are not enough. Teachers need to learn continuously.

Fifth, learning school positively influences the teachers' innovative performance, with the Beta coefficient score of -0.355 or $-35.5 \%$. The present study strengthens the previous findings in that a conducive learning environment can develop the teachers' innovation. Learning organization is characterized by the tension that appears as the catalysis and motivator to learn (Luthans, 2002). It encourages openness to new ideas and the external environment. Besides, it places learning culture as the highest value. The results of other previous study also confirmed that school culture influences innovative performance. Learning culture is considered significant to avoid reification of structure and culture (Wibowo \& Saptono, 2017). This way, the school will develop into a high-performance organization (Syam et al., 2018). Sixth, research by (Paulista et al., 2018), entrepreneurial leadership provided spaces for the principal to optimize the potentials and to motivate the subordinates to work creatively and innovatively. In the same way, the entrepreneurial leadership implemented at school to support changes, innovation, and progress comes from the principal with an entrepreneurial spirit (Mulyasa, 2012). It gives the freedom to the school members to develop their creativity (Chen, 2007). Entrepreneurial leadership and school culture influenced the teachers' innovative performance (Wibowo \& Saptono, 2017). It proves that the competency needs to be applied in the school organization.

Seventh, through learning school, managerial competency has an indirect yet significant influence on the teachers' innovative performance, with a score of 0.233 . Tilar explained that the teachers' performance would be at its best if supported by two aspects: the principal's leadership and the school culture. The teachers' performance would improve with the principal's leadership, organizational culture, and high motivation. The principal serves to motivate and encourage the teachers to work creatively and innovatively. School 
culture influences the teachers' performance (Sahnan, 2016). Based on the analysis, it is clear that the principal's managerial competency influenced the learning school. In other words, with learning school as the medium, the principal's competency indirectly influenced the teachers' innovative performance. In general, the data analysis results indicated that the principal's managerial and entrepreneurial competence did not positively influence the teachers' innovative performance. The teachers and staff can work in a group or individually, but they need the principal's supports. In implementing leadership competency, creativity and innovation play a significant role. Managerial competence influences entrepreneurial competence, which leads to affect organizational performance. Therefore, although the principal has good entrepreneurial competence, without a qualified managerial competence, he cannot optimize the organization members' roles and duties in the attempt to create a learning school environment.

\section{Conclusions and Suggestions}

The analysis concluded with seven findings. First, entrepreneurial competency has no significant influence on learning school. Second, managerial competency has a positive impact on the learning school. Third, entrepreneurial competency has no significant influence on the teachers' innovative performance. Fourth, similarly, managerial competency does not influence the teachers' innovative performance. Fifth, learning school negatively influences the teachers' innovative performance, showing its significant effect. Sixth, entrepreneurial competency through learning school has a positive influence on the teachers' innovative performance. And seventh, managerial competency through learning school has a positive effect on the teachers' innovative performance. The research implies a relative influence of the principal's entrepreneurial and managerial competencies on developing the learning environment and the teachers' innovative performance at school. The findings indicated that innovative performance is a requirement for each teacher. Despite the principal's supports, teachers need to be creative and innovative. Further, the principals need the school members' support to optimize innovation and creativity in the school learning environment.

\section{Acknowledgements}

The researchers express their thankfulness to The Directorate General of Research and Community Development of the Ministry of Education and Culture for the research funding in the form of master's thesis research grants.

\section{References}

Arief, M., Thoyib, A., Sudiro, A., \& Rohman, F. (2013). The Effect of Entrepreneurial Orientation on the Firm Performance through Strategic Flexibility: A Study on the SMEs Cluster in Malang. Journal of Management Research, 5(3), 44-62. https://doi.org/10.5296/jmr.v5i3.3339.

Baidi, \& Suyatno. (2018). Effect of entrepreneurship education, self efficacy and need for achievement toward students' entrepreneurship intention: Case study in FEBI, lain Surakarta, Indonesia. Journal of Entrepreneurship Education, 21(2), 1-16.

Baltaci, A. (2017). Relations between prejudice, cultural intelligence and level of entrepreneurship: A study of school principals. International Electronic Journal of Elementary Education, 9(3), 645-666.

Chen, M. (2007). Entrepreneurial leadershipand new ventures:Creativityon entrepreneurial teams. Creativity and Innovation Management, 16(3), 239-249.

Cogliser, C., \& Brigham, K. (2004). Theintersection ofleadershipand entrepreneurship: Mutuallessonstobe learned.The Leadership Quarterly. 15(6), 771-799. https://doi.org/10.1016Zj.leaqua.2004.09.004.

Collins, L., Hannon, P., \& Smith A. (2004). Enacting entrepreneurial intent:the gaps between student needs and higher education capability. Education \& Training, 46(8/9), 454- 
463. https://doi.org/10.1108/00400910410569579.

Dimovski, Penger, V., Peterlin, S., Uha, J., \& Miha. (2013). Entrepreneurial Leadership in the Daoist Framework. Journal of Enterprising Culture, 21(04), 383-419. https://doi.org/10.1142/s0218495813500167.

Eyal, O., \& Kark, R. (2004). How do transformational leaders transform organisations? A study of the relationship between Leadership and entrepreneurship. Leadership and Policy in Schools, 3(3), 211-235. https://doi.org/10.1080/15700760490503715.

Haris, A. (2018). Kepemimpinan Pendidikan (Teori, Studi Kasus \& Aplikasi) (Kesatu). Alfabeta.

Hisrich, R. D. (1990). Entrepreneurship/intrapreneurship (American p). American psychologist, 45(2), 209.

Hughes, M., \& Morgan, R. E. (2007). Deconstructing the relationship between entrepreneurial orientation and business performance at the embryonic stage of firm growth. Industrial Marketing Management, 36(5), 651-661. https://doi.org/10.1016/j.indmarman.2006.04.003.

Ismuha, Khairudin, \& AR, D. (2016). Kompetensi Manajerial Kepala Sekolah Dalam Meningkatkan Kinerja Guru Pada Sd Negeri Lamklat Kecamatan Darussalam Kabupaten Aceh Besar. Jurnal Administrasi Pendidikan: Program Pascasarjana Unsyiah, 4(1), 46-55.

Jia, B., \& Phillips, R. A. (2014). Efficacy of Networks for Entrepreneurs Raising Finance: A Qualitative Analysis. IUP Journal of Entrepreneurship Development, 11(2), 7-29.

Kunandar. (2007). Guru Profesional Implementasi Kurikulum Tingkat Satuan Pendidikan (KTSP) dan sukses dalam Sertifikasi Guru. Grafindo Persada.

Luthans, F. (2002). Organizational Behavior (10th ed.). McGraw-Hill Higher Education.

Macbeath, J., \& Mortimore, P. (2005). Improving School Effectiveness. Grasindo.

Mahmud, H., \& Palopo, I. (2019). Strategy in Developing Teachers 'Performance at Senior High School. 258(Icream 2018), 202-206.

Mulyasa, E. (2006). Menjadi Guru yang Profesional: Menciptakan Pembelajaran yang Kreatif dan Menyenangkan. Rosdakarya.

Mulyasa, E. (2012). Manajemen dan kepemimpinan kepala sekolah. Bumi Aksara.

Neto, A., Carmo, R. do, Rodrigues, P., Vinícius, Panzer, \& Shannon. (2017). Exploring the relationship between entrepreneurial behavior and teachers' job satisfaction. Teaching and Teacher Education, 63, 254-262. https://doi.org/10.1016/j.tate.2017.01.001.

Nwachukwu, C., Chládková, H., \& Žufan, P. (2017). The Relationship Between Entrepreneurial Orientation, Entrepreneurial Competencies, Entrepreneurial Leadership, and Firm Performance: a Proposed Model. Business Trends, 7(1), 3-16.

Ramadoni, W., Kusmintardjo, \& Arifin, I. (2016). Kepemimpinan Kepala Sekolah Dalam Upaya Peningkatan Kinerja Guru (Studi Multi Kasus Di Paud Islam Sabilillah Dan Sdn Tanjungsari 1 Kabupaten Sidoarjo). Jurnal Pendidikan (Teori Dan Praktik), 1(8), 1500-1504. https://doi.org/http://dx.doi.org/10.17977/jp.v1i8.6620.

Sajilan, S., Hadi, N., \& Tehseen, S. (2015). Impact of Entrepreneur's Demographic Characteristics and Personal Characteristics on Firm's Performance Under the Mediating Role of Entrepreneur Orientation. Review of Integrative Business and Economics Research, 4(2), 36.

Sani Dahiru, A., Akmaliah Lope Pihie, Z., Basri, R., \& Aishah Hassan, S. (2017). Mediating Effect of Teacher Empowerment Between Entrepreneurial Leadership and School Effectiveness. In The Social Sciences 12, Medwell Journals (Vol. 11, pp. 2077-2084).

Senny, M. H., Wijayaningsih, L., \& Kurniawan, M. (2012). Penerapan Gaya Kepemimpinan Transformasional Dalam Manajemen PAUD di Kecamatan Sidorejo Salatiga. 197209.

Suharsaputra, U. (2016). Kepemimpinan Inovasi Pendidikan (Mengembangkan Spirit Entrepreneurship Menuju Learning School) (N. Falah Atif (ed.); 1st ed.). Refika Aditama.

Syam, H., Akib, H., Patonangi, A. A., \& Guntur, M. (2018). Principal entrepreneurship 
competence based on creativity and innovation in the context of learning organizations in Indonesia. Journal of Entrepreneurship Education, 21(Special Issue), $1-13$.

Walid, M., Saragih, M. R., Kunci, K., Organisasi, B., Guru, K., Usman, K., Yusrizal, I., Ibrahimii, S., Darmada, I. K., Dantes, N., Natajaya, N., Suryadinata, L. F., Agam, F., Suparman, L., \& Kerja, B. (2013). Kontribusi Kompetensi Manajerial Kepala Sekolah, Iklim Kerja Dan Motivasi Kerja Terhadap Kinerja Guru SMP Negeri Se Kecamatan Mendoyo Kabupaten Jembrana. Jurnal Magister Manajemen Universitas Mataram, 3(2), 1-25. https://doi.org/10.21831/economia.v9i2.1809.

Wibowo. (2013). Perilaku dalam organisasi. Rajawali Pers.

Wibowo, A., \& Saptono, A. (2017). Kepemimpinan Intrapreneurship, Budaya Sekolah dan Kinerja Inovasi Guru. Jurnal Pendidikan Ekonomi Dan Bisnis (JPEB), 5(2), 176-193. https://doi.org/10.21009/jpeb.005.2.5. 